\title{
In situ long-term modeling of phenanthrene dynamics in an aged contaminated soil using the VSOIL platform
}

\author{
Khaled Brimo a,b,c,d , Patricia Garnier a ${ }^{\text {a }}$ François Lafolie ${ }^{\mathrm{e}}$, Geoffroy Séré ${ }^{\mathrm{b}, \mathrm{c}}$, Stéphanie Ouvrard ${ }^{\mathrm{b}, \mathrm{c}, *}$ \\ a INRA, EcoSys, UMR1405, Université Paris-Saclay, 78850 Thiverval-Grignon, France \\ b INRA, Laboratoire Sols et Environnement, UMR 1120, F-54518 Vandoeuvre-lès-Nancy, France \\ c Université de Lorraine, Laboratoire Sols et Environnement, UMR 1120, F-54518 Vandoeuvre-lès-Nancy, France \\ d Agence de l'Environnement et de la Maîtrise de l'Energie, 20 avenue du Grésillé, BP 90406, F-49004 Angers Cedex 01, France \\ e EMMAH, Université d'Avignon et des Pays de Vaucluse, INRA, 84914 Avignon, France
}

\section{H I G H L I G H T S}

- Phenanthrene fate in an industrial soil was simulated in situ under real conditions.

- Long term biodegradation of phenanthrene followed two degradation phases.

- Prospective climate change effect was investigated.

- Increasing phenanthrene availability significantly enhanced natural dissipation.

\section{A R T I C L E I N F O}

\section{Article history:}

Received 17 July 2017

Received in revised form 13 October 2017

Accepted 8 November 2017

Available online $\mathrm{xxx}$

\section{Keywords:}

Virtual soil platform

PAH reactivity

Industrial contaminated soil

Future climate change

\section{GRA P H I C A L A B S T R A C T}

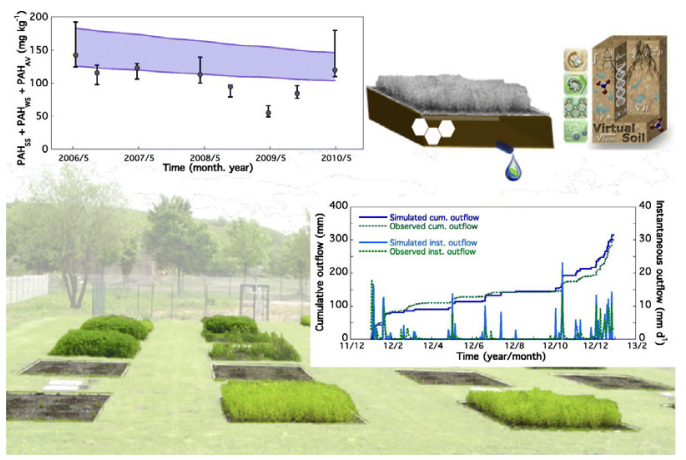

\begin{abstract}
A B S T R A C T
Management and remediation actions of polycyclic aromatic hydrocarbons (PAH) contaminated sites require an accurate knowledge of the dynamics of these chemicals in situ under real conditions. Here we developed, under the Virtual Soil Platform, a global model for PAH that describes the principal physical and biological processes controlling the dynamics of PAH in soil under real climatic conditions. The model was applied first to simulate the observed dynamics of phenanthrene in situ field experimental plots of industrial contaminated soil. In a second step, different long-term scenarios of climate change or bioavailability increase were applied. Our results show that the model can adequately predict the fate of phenanthrene and can contribute to clarify some of unexplored aspects regarding the behavior of phenanthrene in soil like its degradation mechanism and stabilization. Tested prospective scenarios showed that bioavailability increase (through the addition of solvent or surfactants) resulted in significant increase in substrate transfer rate, hence reducing remediation time. Regarding climate change effect, the model indicated that phenanthrene concentration decreased by $54 \%$ during 40 years with a natural attenuation and both scenarios chosen for climatic boundaries provided very similar results.
\end{abstract}

(c) 2017 Elsevier B.V. All rights reserved.
* Corresponding author at: INRA, Laboratoire Sols et Environnement, UMR 1120, F54518 Vandoeuvre-lès-Nancy, France.

E-mail address: stephanie.ouvrard@univ-lorraine.fr (S. Ouvrard).

\section{Introduction}

In the context of remediation operations, site management and environmental risk assessment, an accurate knowledge of organic 
contaminants behavior, biodegradation, transfer or accumulation in the soil medium is necessary. Industrial sites formerly associated with coal exploration and gasworks have frequently been reported to be highly contaminated by persistent organic pollutants (Edwards, 1983; Wilcke, 2000). Among many pollutants, the sixteen polycyclic aromatic hydrocarbons (PAH) defined by the US Environmental Protection Agency (EPA) have been given great interest due to their carcinogenicity, bioaccumulation and persistence in the environment (Iarc, 2010; Tsibart and Gennadiev, 2013). Information of the rates by which these simultaneous processes leading to their concentration's decrease occur in a soil system can help to obtain important management factors, including: i) the time required to reach expected clean up goals; ii) the effects of environmental conditions such as climate and vegetation on the course of the remediation; iii) the impact of additives (e.g. solvents or surfactants) on the decontamination rate and yields. For addressing these issues there is an increasing need for the development of complex models integrating all the relevant processes occurring in such a complex media as soil. Though some existing models simulate the dynamics of PAH in polluted soils, they are not numerous and dominantly focus on a limited number of processes (e.g. the degradation process (Thiele-Bruhn and Brümmer, 2005; Wick et al., 2001), the sorption and aging processes (Johnson et al., 2001) and plant uptake and rhizosphere activity (Takaki et al., 2014)) or at most two processes (Adam et al., 2014; Fragoulis et al., 2005; Geng et al., 2015; Peters et al., 1999; Rein et al., 2016) of the major processes influencing PAH behavior in soil. Actually, with the exception of Peters et al. (1999) and ThieleBruhn and Brümmer (2005) these models have only been tested using experimental laboratory data. Reliable kinetic data for PAH at the field scale remain very scarce (Birdwell et al., 2007; Edwards, 1983). Moreover, as the extrapolation of laboratory kinetic data to field conditions is still not clearly valid as reported by Beulke et al. (2000), the use of these kinetics for predictions at field scale may lead to results far from reality. Generally, two major obstacles have limited the availability of such kinetics for PAH at field scale: i) the absence of appropriate experimental data of long term experiment under real conditions (i.e. with time scale of several years) that are required for models development; ii) the lack of coupled model tools able to simulate simultaneously all the processes occurring in a real soil system. In this latter case, both the little understanding of the complex interaction between the processes and the technological difficulties for implementing such coupled models have been pointed out.

Recently, our group has developed kinetical modules for PAH behavior that proved to be successful at simulating phenanthrene (PHE) experimental incubation results of a contaminated industrial soil at the laboratory scale (Brimo et al., 2016). The present work extends this approach to integrate the previously calibrated "PAH module" in a new coupled model adding transport and transformation processes in the framework of the INRA VSOIL modeling platform (Lafolie et al., 2014). In a first step, the model was calibrated and validated against data acquired on an in situ long-term field experiment (Ouvrard et al., 2011). In a second step, the model was used to assess two scenarios. One aimed at evaluating the long-term evolution of phenanthrene under various prospective climate changes. The second investigated the effect of increasing the mass transfer rate of PHE on its fate in the soil.

\section{Materials and methods}

\subsection{Case study}

\subsubsection{General field conditions}

Data set used for modeling comes from a long-term field experiment initiated in 2005 in order to study, under various management practices, the remediation efficiency of an aged contaminated soil collected from a former coking plant (Ouvrard et al., 2011). The field is located in north-eastern France $\left(49^{\circ} 213 \mathrm{~N}, 5^{\circ} 996 \mathrm{E}\right)$. Mean annual air temperature is $10{ }^{\circ} \mathrm{C}$ and mean annual rainfall amounts to $805 \mathrm{~mm}$ year $^{-1}$ (average data between 2007 and 2014). Atmospheric bulk deposition of 14 PAH (16 US EPA PAH except naphthalene and acenaphthylene) is estimated to be between 19 and $93 \mathrm{ng} \mathrm{m}^{-2} \mathrm{~d}^{-1}$ (Garban et al., 2002). The field devices used for the present study consist in four stainless steel lysimetric plots, and two large-scale lysimeters.

\subsubsection{Field plots}

Twenty-four lysimetric plots were implemented in June 2005 corresponding to 6 treatments repeated 4 times. Each plot (surface area of $2 \times 3 \mathrm{~m}^{2}$ and depth of $0.7 \mathrm{~m}$ ) was filled with an industrial contaminated soil in the top $40 \mathrm{~cm}$ while the bottom $30 \mathrm{~cm}$ was filled with a gravel layer for drainage. In this study we considered the four plots left without vegetation by regular hand weeding. This soil studied has a silty sand texture, neutral $\mathrm{pH}$ and relatively high organic carbon content of $62 \mathrm{~g} \mathrm{C} \mathrm{kg}_{\mathrm{ds}}^{-1}$ (where ds subscript refers to dry soil). The initial 16 US-EPA PAH content was $1924 \pm 258 \mathrm{mg} \mathrm{kg}_{\mathrm{ds}}^{-1}$. Soil was sampled twice a year, in September and in April/May from September 2005 till 2012. For each plot, a representative soil sample of 3 to $4 \mathrm{~kg}$ is obtained from 6 sub-sampling points. At each sampling time, two extraction methods were employed in order to identify and quantify the total and available PAH concentrations. Total concentrations were classically determined by GC-MS analysis following accelerated solvent extraction using dichloromethane and available concentrations were quantified by solid phase extraction using Tenax ${ }^{\circledR}$ (Barnier et al., 2014; Ouvrard et al., 2011).

Drainage water was collected in a tank $(0.4 \times 0.48 \mathrm{~m}$ and $0.6 \mathrm{~m}$ deep) and quantitatively and qualitatively characterized. Water volume was estimated by regular measurement of water level in collection tank. After each measurement, the tanks were emptied until the following one. Thus data correspond to average values over variable time periods, depending on climatic conditions and filling tank rates. Occasionally, for high drainage events, water outflows exceeded the tank storage capacity leading to some uncertainty on the drainage volume. To avoid such data inconsistency, each plot was equipped in 2011 with a tipping counter to measure water outflows volumes with a one-hour time step. Water sampling was performed twice a year in March/April and in September/October for chemical assessment. PAH total dissolved concentrations were estimated using the AquaMS PAH probe (AquaMS, France).

\subsubsection{Lysimeter device}

One lysimeter column (Umwelt-Gerate-Technik, Müncheberg, Germany) ( $1 \mathrm{~m}^{2}$ surface area $\times 2 \mathrm{~m}$ depth) was filled with the same material in April 2008. For this study, the lysimeter was left bare. The column was equipped with time domain reflectometry probes (TDR) and temperature sensors installed at depths $50,100,150 \mathrm{~cm}$ for volumetric water content and temperature monitoring in soil profile respectively. At the bottom, a tipping counter measured the water outflow from the lysimeter. All data were recorded at one-hour time step using a data logger (Séré et al., 2012).

\subsubsection{Climatic data}

Real climatic data were collected with a weather station located at the experimental site (WS STD1, Delta-T Devices). Air temperature, humidity, global incoming solar radiation, rainfall and wind speed were recorded with a one-hour time step. Complementary data collected at Rombas (Meurthe et Moselle, France) weather station located about $9 \mathrm{~km}$ from the experimental field were also used to make up for onsite device failure.

Prospective climatic data, representing future climate conditions in the next decades (between the years 2020 and 2049), have been obtained on the basis of the outputs of global climate model (ALADIN) provided by ANR-SCAMPEI project (http://www.cnrm-game-meteo.fr/ scampei/). Among the greenhouse gas emission scenarios developed on the basis of future economic, social and environmental developments for the zone of the study (Meurthe et Moselle, France), two 
scenarios of future climate changes proposed by IPCC (Intergovernmental Panel on Climate Change) were selected. The scenario A2 (the most intense) assumes a high anthropogenic emissions level in a context of rapid economic growth and based on regional development levels, B1 (the most modest) describes a low greenhouse gas emissions level in a context of greater environmental with introduction of clean and resource-efficient technologies and global development. More details on both scenarios and the hypothesis behind them may be found in the IPCC reports in Houghton et al. (2001) and Nakicenovic and Swart (2000). The monthly and annual averages of main climatic variables (rainfall, evapotranspiration and air temperature) for the both scenarios were summarized in Table SI 1.

\subsubsection{Statistical analysis}

Statistical analyses were performed using R software (Version 3.2.3). Analysis of variance (ANOVA) and the Tukey Kramer HSD test were performed to test if the PHE fractions and the percolated water volumes differed significantly among the four replicates of the bare plots.

\subsection{Model description}

Model building and simulations were achieved using the INRA Virtual Soil Platform (Lafolie et al., 2014; https://www6.inra.fr/vsoil). Detailed information about the platform and how the model was built within this platform is available in the Supporting information (SI).

Briefly, the coupled PAH model is one-dimensional and is composed of five main modules: heat transport, water flow, solute transport, $\mathrm{PAH}$ sorption and PAH biodegradation (Fig. 1). The climatic data (evapotranspiration (ETP), rainfall (R), air temperature $\left(T_{s}\right)$ ) are provided by specific modules considered as boundary conditions. This study focused on soil processes without any plant effect and no modules associated to plant processes were implemented at this stage. PAH atmospheric deposits were considered minor compared to PAH soil concentrations, and not considered as well. Fig. 1a shows the relationships between the modules and the information they exchange as input variables and output variables. Heat transport module computes heat flow and soil temperature distributions in the soil profile using the convection diffusion equation. Water flow module computes water outflow, water content and water potential distributions in the soil profile using Richards equation (Richards, 1931). Solute transport module simulates the transport of the solute species, here PAH, in the soil solution using the advection-dispersion equation. The mathematical algorithms and numerical solutions adopted for these three aforementioned modules were taken from Lafolie (1991). The PAH biodegradation and sorption modules simulate PAH dynamics in soil including biodegradation and sorption processes. These were developed specifically and previously published by Brimo et al. (2016). Biodegradation module simulates the degradation of the solute species of $\mathrm{PAH}\left(\mathrm{PAH}_{\mathrm{AV}}\right.$, where "AV" subscript refers to available) using two biodegradation pathways. The co-metabolic pathway (plotted in dashed lines Fig. 1b) uses first order kinetics and the specific biodegradation pathway uses Monod equation (plotted in pointed lines Fig. 1b). Coefficients controlling soil water content and temperature dependence of degradation proposed respectively by Recous (1995) and Andrén et al. (1992) were also considered in the development of this module. The module computes the growth of the specific biomasses, $\mathrm{B}_{\mathrm{SPE}}$, the metabolites formation, $\mathrm{PAH}_{\mathrm{MET}}$, the production of $\mathrm{CO}_{2}, \mathrm{PAH}_{\mathrm{CO} 2}$, and the formation of biogenic bounded residues, $\mathrm{PAH}_{\mathrm{BS}}$. Sorption module computes both the weakly sorbed ( $\mathrm{PAH}_{\mathrm{WS}}$, where "WS" refers to weakly sorbed) and the strongly sorbed ( $\mathrm{PAH}_{\mathrm{SS}}$, where "SS" refers to strongly sorbed) fractions for PAH as result of sorption on soil solid fraction. Both processes are described using bi-phasic first order kinetics model.

\subsection{Modeling methodology}

The objectives were i) to calibrate and validate the model on past time series ii) to use the validated model for prediction scenarios, first, under variable climatic conditions as might be expected from global warming effect, and under forceful increase in contaminant availability.
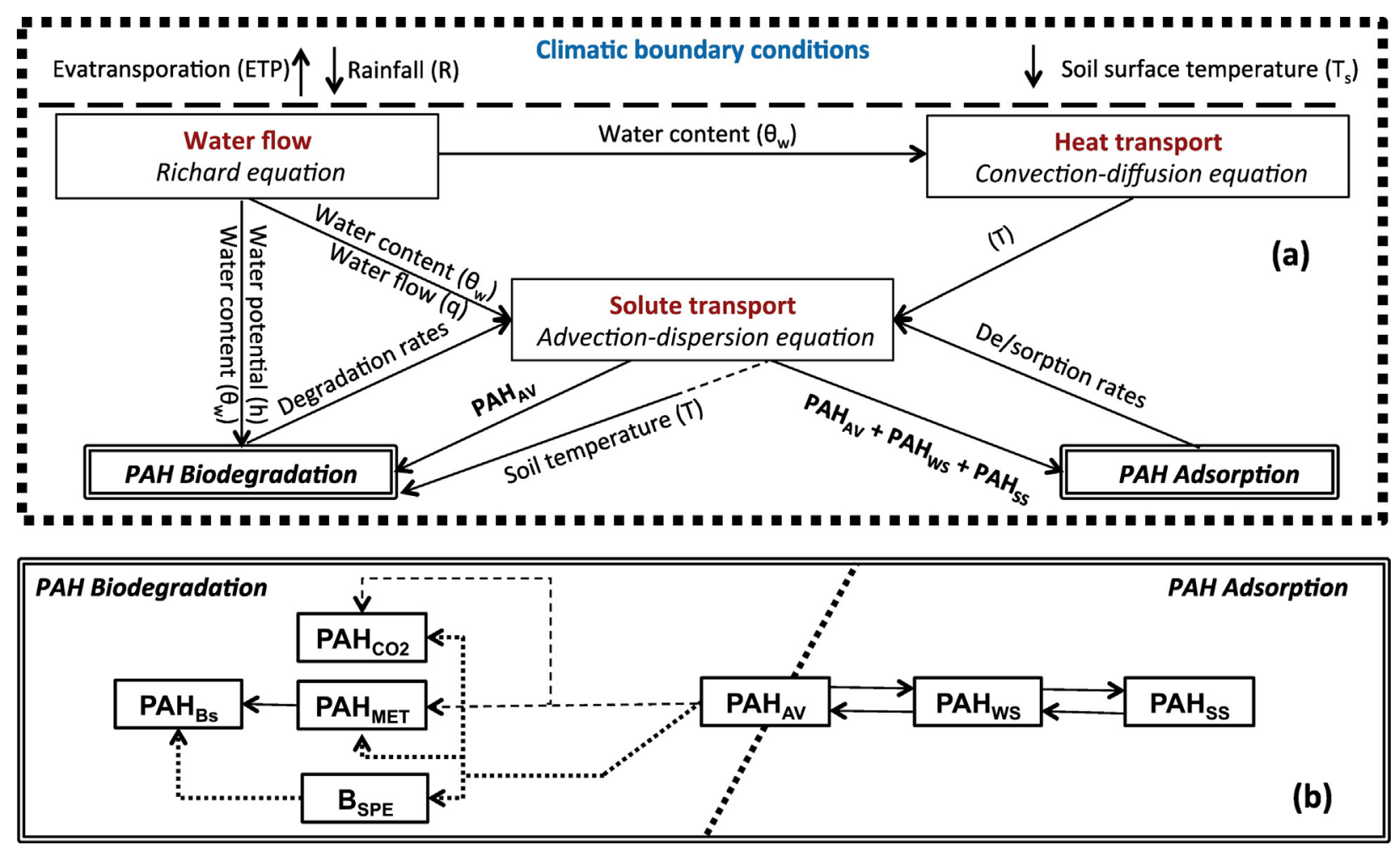

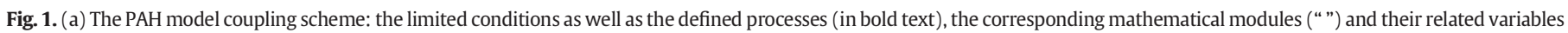

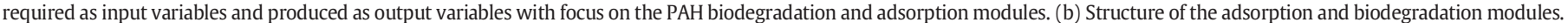




\subsubsection{Model calibration}

When this study was performed in 2016, the calibration procedure in VSOIL could only be manual. So, here the fitted parameters were adjusted manually by trial and error procedure based on visual fitting between observed and simulated data sets. The performance of the model calibration/validation was then evaluated using different statistic criteria as described later in Section 2.4.

To start with, both water flow and heat transport modules were calibrated. This step was performed using the hydraulic and thermal experimental data collected from the lysimeter device. The Van Genuchten (1980) soil hydraulic functions with the model of Mualem (1976) were implemented to describe the soil water retention and the hydraulic conductivity functions. A polynomial formulation linking soil thermal conductivity to soil water content taken from Garnier et al. (2001) was selected to describe the thermal conductivity curves.

Model calibration continued by calibrating the PAH modules (corresponding to the biodegradation and sorption modules) to simulate PHE data obtained on the lysimetric plots over the first eight measurement points of our data set from May 16, 2006 until April 26, 2010. The water flow parameters optimized were then used to simulate the lysimetric plots. Then, starting from the default parameter values obtained from calibration study using laboratory data (Brimo et al., 2016), a new set of parameters was derived by fitting three parameters: $k_{M}, k_{S W}$ and $\mu s_{\max }$ while fixing the other parameters to their default values (see Table 2 for parameters description). The parameters $k_{M}$ and $k_{S W}$ were chosen because they were not optimized in the previous study due to short experimental time (they were left fixed to zero). The parameter $\mu \mathrm{s}_{\max }$ was also chosen as it proved to have significant influence both independently and in conjunction with other model parameters including $k_{S W}$ and $k_{M}$ on the model simulation results, as previously assessed by a global sensitivity test (Brimo et al., 2016). We chose to set $\mu s_{\max }$ to a realistic value taken from the literature describing in situ PHE degradation in a soil of a former coke plant to improve the model prediction due to lack of experimental data on the mineralization quantities.

\subsubsection{Model validation}

The model was then validated using the last five measurement points of our data set from September 27, 2010 until September 27, 2012 for water content and PAH dynamics.

\subsubsection{Model scenarios}

Finally, the validated model was further used to explore the effect of two factors: climate and pollutant availability.

In the first case, we aimed at evaluating climate change impact on long-term ( 40 years) fate of PHE. To do so and using as initial conditions the data measured in September 27, 2010, we run two identical model simulations during the period from September 27, 2010 to December 31,2049 . The only difference between the two simulations was the input meteorological data sets. The meteorological data used for these simulations were the climatic data from the local weather station over the first ten years (simulation period between September 27, 2010 and December 31,2019) taken on the basis of randomized past data selection and completed by the climatic data provided by the two scenarios of future climate changes (A2 or B1) for the last 30 years of simulation period (ANR-SCAMPEI project). Hence, difference between the two climate change scenarios was only over the last 30 years of simulation period.

In the second case, we artificially increased PHE availability several times, as it might be obtained after the addition of solvents or surfactants. To do so, we run the model over a 5 years period (from September 27, 2010 until September 27, 2015) with increased $k_{S W}$ values $(2,5,10$ folds) corresponding to a 2, 5, 10 fold increase of substrate transfer rate from $\mathrm{PAH}_{\mathrm{SS}}$ to $\mathrm{PAH}_{\mathrm{Ws}}$.

\subsubsection{Initial and boundary conditions}

Water flow and heat transport modules were calibrated using data collected from lysimeter. The lysimeter geometry was represented in the model with simulation depth of $200 \mathrm{~cm}$. The upper water flow boundary condition ( $0 \mathrm{~cm}$ depth) was set by the daily atmospheric conditions (rainfall and evapotranspiration) and the lower boundary condition (respectively depth $40 \mathrm{~cm}$ in plot and $200 \mathrm{~cm}$ in lysimeter) was the free drainage. The potential evapotranspiration values (ETP) were calculated from the collected climatic data using Penman-Monteith equation (FAO 56-Method). The upper solute transport boundary condition was defined as Cauchy boundary condition. The upper heat transport boundary condition was specified as the hourly soil surface temperature and a free temperature condition was applied as boundary condition. The initial conditions for water flow and heat transport were assigned in terms of volumetric water content and soil temperature values at the beginning of each simulation. The lysimetric plot was considered as one-dimensional domain with a simulation depth of $40 \mathrm{~cm}$ that was discretized into one layer by a finite element mesh.

When PAH dynamics were simulated in plot, we started our simulations to coincide at one of soil sampling times. The initial conditions for sorption and biodegradation modules were therefore taken as follows: $\mathrm{PAH}_{\mathrm{CO}}, \mathrm{PAH}_{\mathrm{BS}}$ and $\mathrm{PAH}_{\mathrm{MET}}$ were all considered null; the initial specific biomass concentration was always taken equal to $0.575 \mathrm{mg} \mathrm{C} \mathrm{kg} \mathrm{ds}^{-1}$ (equivalent to $0.61 \mathrm{mg}$ PHE $\mathrm{kg}_{\mathrm{ds}}^{-1}$ ) as reported by Cebron et al. (2009), while the values of $\mathrm{PAH}_{\mathrm{WS}}, \mathrm{PAH}_{\mathrm{AV}}$ and $\mathrm{PAH}_{\mathrm{SS}}$ were derived from the PHE measured data described in Section 2.1.2. The quantity of PHE extracted with Tenax represented the total bioavailable fraction $\left(\mathrm{PAH}_{\mathrm{AV}}\right.$ $+\mathrm{PAH}_{\mathrm{WS}}$ ) found in both aqueous and sorbed phases. The quantity extracted with dichloromethane represented the sum of the total bioavailable fraction and the aged fraction (i.e. $\mathrm{PAH}_{\mathrm{AV}}+\mathrm{PAH}_{\mathrm{WS}}+\mathrm{PAH}_{\mathrm{SS}}$ ). Thus, the aged fraction, $\mathrm{PAH}_{\mathrm{SS}}$, was obtained from subtracting the total bioavailable fraction from the total extracted PHE fraction at each sampling time. The amount of PHE in solution that was viewed as $\mathrm{PAH}_{\mathrm{Av}}$ of the model was calculated from the total bioavailable fraction considering that the PHE recovered by Tenax was sorbed on soil (i.e. neglecting contribution of soluble PHE, being $1 / 1000$ to $1 / 960$ of the total) using the sorption distribution coefficient $K_{d}\left(\mathrm{~L} \mathrm{~kg}_{\mathrm{ds}}^{-1}\right)$ as following:

$K_{d}=\frac{\text { sorbed PAH compound recovered by Tenax }\left(\mathrm{mg} \mathrm{kg}_{\mathrm{ds}}^{-1}\right)}{\mathrm{PAH}_{\mathrm{AV}}}$

The $K_{d}$ value was obtained using:

$K_{d}=K_{O C} f_{O C}$

where $f_{O C}$ is the organic carbon content in soil (here $63 \mathrm{~g} \mathrm{C} \mathrm{kg} \mathrm{ds}^{-1}$ ) and $K_{O C}$ is the sorption distribution coefficient normalized to $f_{O C}$, which can be calculated using the correlation taken from Nguyen et al. (2005):

$\log K_{O C}=1.14 \log K_{o w}-1.02$

where $K_{o w}$ is the octanol-water partition coefficient and $\log K_{o w}$ value is 4.57 for phenanthrene (Mackay et al., 2006).

As well, we assumed uniform concentrations of the soil microbial biomass and PHE along the soil profile (between 0 and $40 \mathrm{~cm}$ ) because they were all taken from soil samples collected over the whole profile depth. In the current study and based on the conclusion of our previous work that the specific biodegradation pathway is the most significant at explaining PHE biodegradation (Brimo et al., 2016), the co-metabolism biodegradation pathway was neglected (i.e. $k_{\text {deg }}=0 ; \beta=0$ ).

\subsection{Goodness of fit criterions and simulation uncertainty}

The simulated surfaces were obtained by stochastic simulations through running the model using the 95\% confidence intervals of PHE input data (i.e. the initial concentrations) defined at the beginning of 
every simulation. The uncertainty in model parameters (i.e. their 95\% confidence interval values) could not be included due to excessive simulation time requirements. The quantitative assessment of the model performances for the calibration and validation periods was calculated using the 50th percentile (i.e. median value).

We applied the following statistical criteria in order to assess our model correctness: Nash-Sutcliffe model efficiency index NS (Nash and Sutcliffe, 1970), Theil's inequality coefficient $U^{2}$ (Power, 1993) and the chi-squared test $\chi^{2}$ (FOCUS, 2006) as well as the correlation coefficient corr (Fisher, 1958). The mathematical formulations of these criteria are given in appendix (SI). NS $=1$ indicates a perfect agreement between the simulated and the observed data while $N S \leq 0$ indicates that the model provides less accurate predictions than the mean value of the observed data. Conversely best model performance results in $U=0$, while $U>1$ indicates that the model performs worse than using past observations to describe future conditions. The $\chi^{2}$ test considers the deviations between observed and predicted values relative to the uncertainty of the measurements. The $\chi^{2}$ calculated for a specific fit at a given degree of freedom should be below $15 \%$ (at 5\% significance error). The correlation coefficient (corr) is calculated using the function "corrcoef" in MATLAB where a correlation value of 1 indicates that the model and the observations have the same variance.

\section{Results and discussion}

\subsection{Model calibration and validation}

\subsubsection{Heat and water flow}

The parameters used for simulating the heat and water flow are given in Table 1 . All heat flow parameters were taken from Garnier et al. (2001). The parameters of the van Genuchten equation, $\theta_{r}, l, n, K_{s}$, were predicted from our soil textural properties (sand: $62.9 \%$, silt $24.1 \%$ and clay $13 \%$ ) using the ROSETTA code (Schaap et al., 2001) whereas the two other ones, $\theta_{s}$ and $\alpha$, were optimized using the hydraulic data observed in the lysimeter column (results not shown). Once calibrated on the lysimeter column data, these parameters were then used to simulate lysimetric plots hydraulic behavior. For water outflow both the exact timing of the onset of drainage and the peak discharge were generally perfectly simulated (Figs. SI 3, SI 4) as confirmed by NS, $U$ and corr values close to ideal values (Table SI 2). For soil temperature,

Table 1

Physical parameters used in PAH coupled model to simulate water, heat, and solute species.

\begin{tabular}{|c|c|}
\hline Parameters & Values \\
\hline \multicolumn{2}{|l|}{ Water flow } \\
\hline Saturated volumetric water content, $\theta_{s}\left(\mathrm{~m}^{3} \mathrm{~m}^{-3}\right)$ & $0.3454^{\mathrm{a}}$ \\
\hline Residual volumetric water content, $\theta_{r}\left(\mathrm{~m}^{3} \mathrm{~m}^{-3}\right)$ & $0.0471^{\mathrm{b}}$ \\
\hline Inverse of the air-entry value, $\alpha\left(\mathrm{m}^{-1}\right)$ & $0.10^{\mathrm{a}}$ \\
\hline Pore-size distribution index, $n(-)$ & $1.3910^{\mathrm{b}}$ \\
\hline Pore-connectivity parameter, $l(-)$ & $0.5^{\mathrm{b}}$ \\
\hline Saturated hydraulic conductivity, $K_{s}\left(\mathrm{~m}\right.$ day $\left.^{-1}\right)$ & $0.3152^{\mathrm{b}}$ \\
\hline \multicolumn{2}{|l|}{ Heat transport } \\
\hline Heat capacity of the solid phase of each layer $\left(\mathrm{J} \mathrm{kg}^{-1} \mathrm{~K}^{-1}\right)$ & $800^{\mathrm{c}}$ \\
\hline $\begin{array}{l}\text { Term of degree } 0 \text { in the polynomial formulation of the thermal } \\
\text { conductivity coefficient as a function of water content } \\
\left(\mathrm{W} \mathrm{m}^{-1} \mathrm{~K}^{-1}\right)\end{array}$ & $0.5^{c}$ \\
\hline $\begin{array}{l}\text { Term of degree } 1 \text { in the polynomial formulation of the thermal } \\
\text { conductivity coefficient as a function of water content } \\
\left(\mathrm{W} \mathrm{m}^{-1} \mathrm{~K}^{-1}\right)\end{array}$ & $2^{c}$ \\
\hline \multicolumn{2}{|l|}{ Solute transport } \\
\hline Longitudinal dispersivity $(\mathrm{m})$ & $0.01^{\mathrm{d}}$ \\
\hline Molecular diffusion coefficient $\left(\mathrm{m}^{2}\right.$ day $\left.^{-1}\right)$ & $0.3776 \cdot 10^{-4 e}$ \\
\hline \multicolumn{2}{|l|}{ a Value optimized in the present study. } \\
\hline \multicolumn{2}{|l|}{ b Value predicted by ROSETTA code (Schaap et al., 2001). } \\
\hline \multicolumn{2}{|c|}{ c Value taken from Garnier et al. (2001). } \\
\hline \multicolumn{2}{|c|}{$\begin{array}{l}\text { d Value predicted by the empirical relationship reported by Schulze-Makuch (2005). } \\
\text { e Value taken from Gustafson and Dickhut (1994). }\end{array}$} \\
\hline
\end{tabular}

since no data were available on lysimetric plots, parameters were checked against lysimetric column data. A satisfactory correspondence between observed and model-predicted values was found as confirmed with high $N S$ value equal to 0.76 . Nevertheless, the model tended to underestimate temperature values at $50 \mathrm{~cm}$ depth during dry periods by about $3.28^{\circ} \mathrm{C}$ (Fig. SI 5). We suspect the major reason of this was related to setting ambient air temperature (instead of soil surface temperature) for the upper limit condition, due to lack of data. However, this discrepancy should not have a considerable effect on simulation results of PHE degradation as the water content during dry periods is reported to have more significant limitation on biological activity than the temperature (Alletto et al., 2006).

\subsubsection{Biodegradation and adsorption modules}

The parameter sets previously obtained for PAH biodegradation and adsorption modules (Brimo et al., 2016) required additional parameter calibration before being used. This was quite expected since those parameters were determined using short-time laboratory incubation data and therefore at this time scale and under controlled conditions aging time and effects of varying conditions of soil temperature and water content were not taken into account. The new parameter sets are given in Table 2.

The $\mu s_{\max }$ value was set equal to $0.0171 \mathrm{~d}^{-1}$ to correspond to the obtained values of Thiele-Bruhn and Brümmer (2005), who investigated the kinetics of PHE degradation for a long term PAH contaminated soil from a former coking plant using outdoor plot trials over a period of 168 weeks. In fact, the chosen value for $\mu s_{\max }$ is two orders of magnitude lower than the typical specific bacterial growth rate values simulated by batch culture experiments with freshly spiked soil samples over short time periods. Over 2 to 12 days experiment, $\mu \mathrm{s}_{\max }$ values were reported to be within the range of 0.135-3.8 d $\mathrm{d}^{-1}$ (Adam et al., 2014; Keuth and Rehm, 1991; Rein et al., 2016; Tao et al., 2007; Weissenfels et al., 1990). Nevertheless, our adopted value for $\mu s_{\max }$ appeared to be more realistic as the aforementioned values of $\mu \mathrm{s}_{\max }$ were all determined under laboratory conditions of non-limiting growth for the bacteria degraders with high PHE concentrations in the aqueous phase (few hundreds of $\mathrm{mg} / \mathrm{L}$ ). The higher is the aqueous concentration of a $\mathrm{PAH}$, the higher is its biodegradation by degrading bacteria. Volkering et al. (1992) also reported a low value of $0.0072 \mathrm{~d}^{-1}$ for the specific growth rate on anthracene (another 3-ring PAH like phenanthrene) when this substrate concentration was low (i.e. $0.075 \mathrm{mg} / \mathrm{L}$ ).

Table 2

Parameter sets for PAH biodegradation and PAH adsorption modules. Only values in bold characters were optimized in this study, the others were previously estimated in Brimo et al. (2016).

\begin{tabular}{|c|c|c|}
\hline Symbol & Description & Value \\
\hline $\mathrm{k}_{\mathrm{AW}}$ & $\begin{array}{l}\text { First order kinetic constant that goes } \\
\text { from } \mathrm{PAH}_{\mathrm{AV}} \text { into } \mathrm{PAH}_{\mathrm{WS}}\left(\text { day }^{-1}\right)\end{array}$ & 55.7250 \\
\hline $\mathrm{k}_{\mathrm{WA}}$ & $\begin{array}{l}\text { First order kinetic constant that goes } \\
\text { from } \mathrm{PAH}_{\mathrm{WS}} \text { into } \mathrm{PAH}_{\mathrm{AV}}\left(\text { day }^{-1}\right)\end{array}$ & 0.0567 \\
\hline $\mathrm{k}_{\mathrm{WS}}$ & $\begin{array}{l}\text { First order kinetic constant that goes } \\
\text { from } \mathrm{PAH}_{\mathrm{WS}} \text { into } \mathrm{PAH}_{\mathrm{SS}}\left(\mathrm{day}^{-1}\right)\end{array}$ & 0.0582 \\
\hline$k_{S W}$ & $\begin{array}{l}\text { First order kinetic constant that goes } \\
\text { from } \mathrm{PAH}_{\mathrm{SS}} \text { into } \mathrm{PAH}_{\mathrm{WS}}\left(\mathrm{day}^{-1}\right)\end{array}$ & 0.0006 \\
\hline$\mu s_{\max }$ & Maximum specific growth rate $\left(\right.$ day $\left.^{-1}\right)$ & $\mathbf{0 . 0 1 7 1}^{\mathrm{a}}$ \\
\hline $\mathrm{ks}_{\text {spe }}$ & $\begin{array}{l}\text { Half saturation of growth substrate for } \\
\text { the specific biomass ( } \mathrm{mg} \text { PHE } \mathrm{kg}_{\mathrm{ds}}^{-1} \text { ) }\end{array}$ & 0.0356 \\
\hline$Y_{\text {spe }}$ & Yield of specific biomass $(-)$ & 0.1270 \\
\hline$k_{M}$ & Mortality rate constant $\left(\right.$ day $\left.^{-1}\right)$ & 0.0015 \\
\hline$\alpha$ & $\begin{array}{l}\text { Magnitude of metabolites production } \\
\text { by biodegradation for specific biodegradation }(-)\end{array}$ & 0.0121 \\
\hline $\mathrm{k}_{\mathrm{MB}}$ & $\begin{array}{l}\text { First order kinetic constant that goes } \\
\text { from } \mathrm{PAH}_{\mathrm{MET}} \text { into } \mathrm{PAH}_{\mathrm{Bs}}\left(\text { day }^{-1}\right)\end{array}$ & 0.0006 \\
\hline$k_{d e g}$ & $\begin{array}{l}\text { Pseudo first order kinetic constant of } \\
\text { biodegradation for co-metabolism }\left(\text { day }^{-1}\right)\end{array}$ & - \\
\hline$\beta$ & $\begin{array}{l}\text { Magnitude of metabolites production by } \\
\text { biodegradation for co-metabolism }(-)\end{array}$ & - \\
\hline
\end{tabular}

${ }^{\mathrm{a}} \mu \mathrm{s}_{\max }$ value taken from (Thiele-Bruhn and Brümmer, 2005). 
According to Wick et al. (2001) the mortality rate $k_{M}$ varied between 5 and $10 \%$ of $\mu \mathrm{s}_{\max }$. The estimated $k_{M}$ value of $0.0015 \mathrm{~d}^{-1}$ was within that range. The low fitted value of decay rate, $k_{M}$, might reflect the capacity of PHE degraders to live and grow with very low concentrations of substrate in the aqueous phase. This low available fraction is the direct consequence of the substrate transfer limitation in a soil where contamination aged for years or decades. This suggests that these microorganisms are well adapted or have adapted to survive in their substrate-limited environment.

The $k_{S W}$ value of $0.0006 \mathrm{~d}^{-1}$ was in the ranges of values reported by Johnson et al. (2001) for the apparent first order kinetic constants for slow desorption processes of PHE given in contaminated soils aged $>250$ days.

Fig. 2a to e present the comparison between the predicted and observed average PHE data over the calibration and validation periods. The results confirm the suitability of the model to describe the in situ dynamics of PHE, as confirmed by the good values of the different goodness of fit criteria. Hence, over the calibration period these criteria reached: $\chi^{2}=0.317, N S=0.78$ and $U=0.31$ whereas over the validation period we obtained: $\chi^{2}=0.294, N S=0.97$ and $U=0.12$. Thus the model yielded better prediction for the validation period than the calibration one. This unusual result may come from the high uncertainty in measured total PHE data for three successive dates of calibration period (September 2008, April 2009 and September 2009, Fig. 2a), when the model largely overestimated the amounts measured for PHE.

The total PHE concentration globally displayed a continuous decrease that appeared to slow down with time, when comparing calibration and validation periods (respectively Fig. $2 \mathrm{a}$ and b). The bioavailable amount dynamics appeared more cyclic with increases during the cold seasons (from October to April) and decreases during the warm seasons (from May to September) (Fig. 2c and d). We suspect that the major reason for this was the reduction and enhancement respectively in the biodegradation process that occurred in cold seasons and warm seasons in accordance with the variations of temperature of the soil profile. Fig. SI 6 reveals that when the temperature of the soil profile decreased in cold periods, the environmental conditions likely became less favorable for $\mathrm{PAH}$ degraders growth and reverse in warmer periods. This gives first evidence that the environmental conditions might impact the biological activity and therefore the fate of PAH in soil.

The solute fraction of PHE was not measured individually but total dissolved PAH concentration was regularly recorded. The predicted
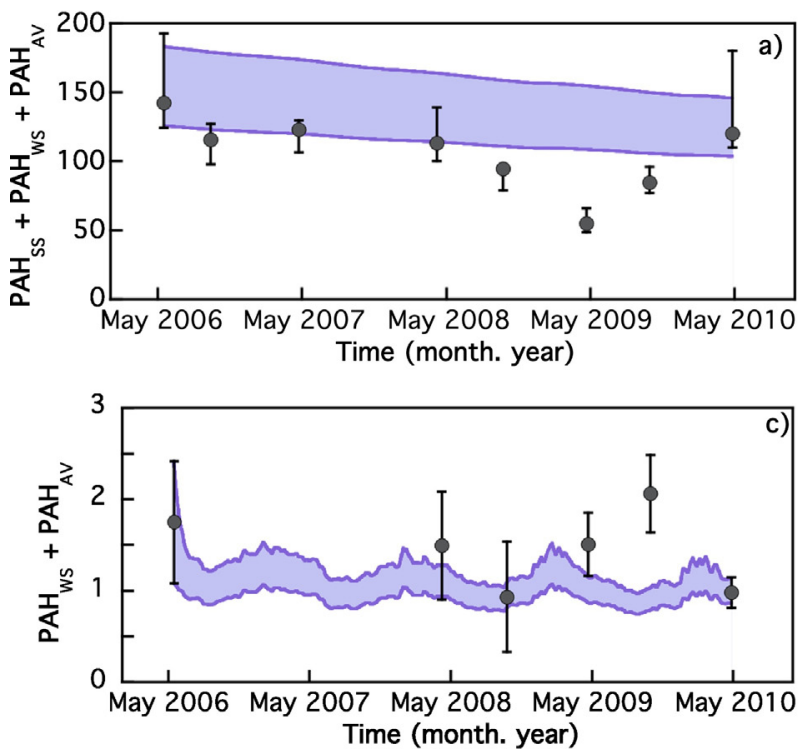

soluble PHE concentration and measured total dissolved PAH in leachates behaved similarly. Both breakthrough curves displayed the same onset and tended to run parallel over both calibration and validation periods (Fig. SI 7). This was confirmed by high correlation index between both curves with values $>0.97$ and 0.99 respectively for calibration and validation periods. The predicted sums of the leached PHE at $40 \mathrm{~cm}$ depth of the soil profile were respectively 0.38 and $0.22 \mathrm{mg} \mathrm{m}^{-2}$ over the calibration and validation periods considered. Thus, over 300 and 237 days, the mean daily leached rates of PHE were respectively 1.27 - $10^{-3}$ and $9.21 \cdot 10^{-4} \mathrm{mg} \mathrm{m}^{-2} \mathrm{~d}^{-1}$. Moreover, simulation results showed that at end of calibration and validation periods respectively, the total leached PHE amount at $40 \mathrm{~cm}$ depth of the soil profile represented $<0.006$ and $0.003 \%$ of the initial PHE content of the soil profile. Regarding microorganisms, the model predicted a slow increase of PHE degraders over the 2 first years of simulation that tended to stabilize afterwards. Experimental results reported by Ouvrard et al. (2011) showed no significant increase of PAH-degrading population over the same calibration period. According to our simulations, the most significant dissipation pathway for PHE in the soil is the mineralization of PHE into $\mathrm{CO}_{2}$. The model predicted that, at end of the simulation periods, the mineralized quantity of PHE into $\mathrm{CO}_{2}$ was about 16.3 and $5.8 \%$ of the total initial PHE content in the soil for calibration and validation periods respectively, followed by the amounts of PHE converted into biological bounded residues which represented about 2.1 and $0.78 \%$ respectively. The produced amounts of metabolites represented $<0.13$ and $0.07 \%$ of the total initial PHE content in soil for calibration and validation periods respectively. The importance of biogenic origin for residues has already been pointed out by Kästner et al. (2014), in the case of PAH. In this case, parent compounds strong sorption and metabolites could account to levels as low as $0.5 \%$ of initial amounts.

\subsection{Long-term (2010-2049) prediction of phenanthrene under variable climatic prospective conditions}

This prospective simulation aimed at exploring the long-term fate of PHE in the aged soil subject to natural attenuation (without plants and without any treatment efforts). An additional goal of the scenario was to analyze the influence of projected future climate changes on PHE fate and behavior in that soil.

Over the 40 years of simulation, both scenarios applied similar climatic data for the 10 first years and differed only for 30 last years. Fig.
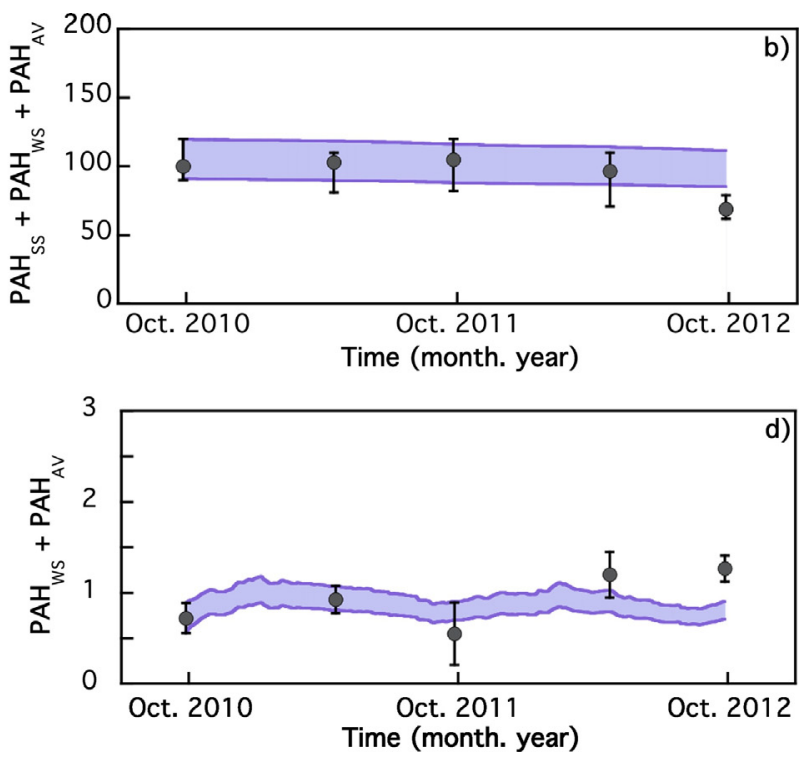

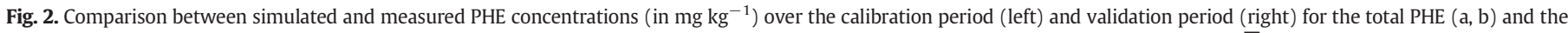

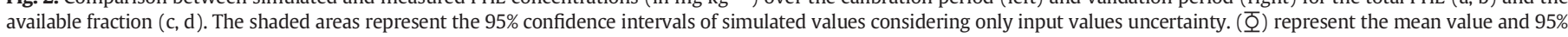
confidence intervals of observed data considering all uncertainties. 
SI 8 presents the predicted mean annual air temperatures over time for both scenarios. Both climatic scenarios, A2 and B1 predicted that air temperatures would be higher in the few next years but with a little linear increase in scenario B1 compared to A2 (increasing rates are $0.00512 \mathrm{x}$ and $0.0051 \mathrm{x}$ for $\mathrm{B} 2$ and $\mathrm{A} 1$ respectively where $\mathrm{x}$ stands for the year at which the future temperature is calculated). They also differed significantly on the amount of water reaching the soil surface (Fig. SI 9) with cumulated values over the 40 years of $6932 \mathrm{~mm}$ and $5178 \mathrm{~mm}$ for A2 and B1 respectively (i.e. 1.34 folds more for A2 compared to B2). This latter was calculated by subtracting accumulated evapotranspiration flux (ETP) from accumulated rainfall flux. This increase in volume of water for scenario A2 compared to B1 was related to, respectively, decrease and increase of the predicted ETP and rainfall flux values through the last 30 years simulation periods as was described in Table SI 1 (i.e. between 2020 and 2049 the mean annual ETP varied between 593 and $634 \mathrm{~mm}$ whereas mean annual rainfall varied between 777 and $760 \mathrm{~mm}$ for scenario A2 and scenario B1 respectively). Consequently, the combined effects of meteorological factors including precipitations, ETP, and air temperatures contribute in generating more preferential conditions of soil water content and temperature for PHE bacteria degraders in A2 compared to B1. A little increase and decrease respectively in soil water content and temperature was observed in A2 compared to B1 (see Fig. SI 10).

The simulated curves of the dynamics of PHE using the two meteorological data sets (A2 and B1) are given in Fig. 3a to e. All variables are expressed as the percentages of the initial total measured amount of PHE in the soil profile $(0-40 \mathrm{~cm})$.

For both climatic prospective conditions, simulation results indicated that PHE extractible fraction displayed bi-phasic loss with a first phase of about 39\% decrease over the 13 first years and a second phase with an additional 15\% decrease in the 27 following years (Fig. 3a). Similarly, the production rates of both biological bounded residues $\left(\mathrm{PAH}_{\mathrm{BS}}\right)$ and the mineralized amount into $\mathrm{CO}_{2}\left(\mathrm{PAH}_{\mathrm{CO} 2}\right)$ were found to be much more important in the first phase compared to the second phase (Fig. $3 c$ and $d$ respectively). The evolution of the specific microbial biomass $\left(B_{S P E}\right)$ accumulated in the soil profile (Fig. 3f.) increased over the first
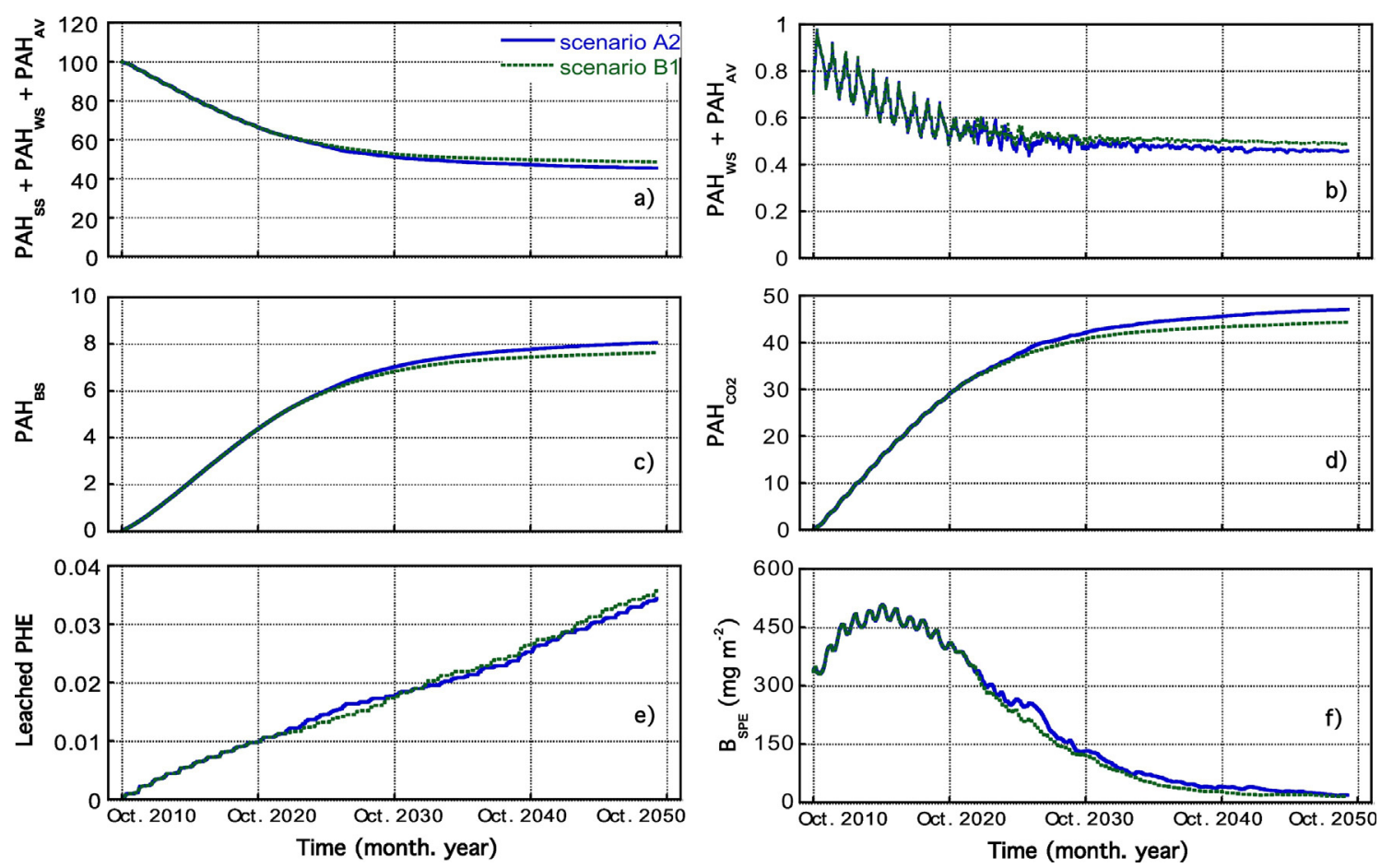

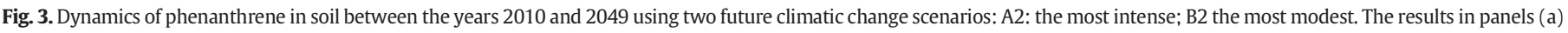

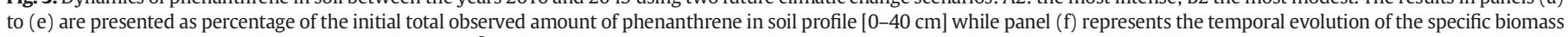
accumulated in soil profile expressed by unit of $\mathrm{mg} \mathrm{m}^{-2}$. 
explained by modifying the degradation rate resulting from the difference of temperature and soil water content conditions between the both scenarios.

Fig. 3e presents PHE leaching for both scenarios. The leaching rate of PHE was found to be higher (by a factor of 1.2) in B1 compared to A2, which was consistent with findings reported for pesticides showing that leaching to groundwater increases with increasing persistence (Soutter and Musy, 1999; Tiktak et al., 1994). These results clearly highlight that climate conditions are factors that can affect the efficiency of the natural remediation of PAH in contaminated soil and should therefore be accounted for in future management practices.

\subsection{Effect of simulated increase in PHE desorption rate}

This scenario tried to approximate an alternative strategy that would increase the mass transfer of contaminant substrate such as an addition of solvents or surfactants (e.g. alcohol ethoxylate, glycoside, triton X-100, tween 80). As expected (Laha et al., 2009; Madesen and Kristensen, 1997), simulation results showed an increase in the degradation rate with the increase of the translocation rate of the substrate from the $\mathrm{PAH}_{\mathrm{SS}}$ into $\mathrm{PAH}_{\mathrm{wS}}$ compartment (Fig. 4). It provided further evidence that delivering the substrate to bacteria degraders was the main limitation to biodegradation. Interestingly the increase in degradation was not fully proportional to the increase of the desorption rate. As an example, when the desorption rate was doubled a remediation level was reached in 6 years (including 40\% PHE mass loss into $\mathrm{PAH}_{\mathrm{CO} 2}$ and $\mathrm{PAH}_{\mathrm{BS}}$ ) instead of 14 years. Thus any technology achieving this effect of increased desorption rate, when combined with bioremediation strategy enhancing and/or maintaining high biological activity, might be a real asset for remediation of contaminated sites of former industrial activities.

However, this strategy also increases PHE exposure. Indeed, the concentration of bioavailable fraction (Fig. 4b) and the leaching rate into groundwater (Fig. 4e) are enhanced thus increasing the potential toxicity risks. Such factors should be kept in mind when a decision concerning the remediation strategy has to be made. It is also important to indicate that our simulation results for this scenario did not consider the real method by which such an increase in bioavailability could be achieved. For instance any addition of surfactant or extracting solvents could also have an effect on the biological activity. Such inhibition, including toxicity, of surfactant on the microorganisms' growth has already been pointed out (Aronstein et al., 1991; Li and Chen, 2009; Mosche and Meyer, 2002).

\section{Conclusion}

Based on the experimental data of a long term field experiment, this study was dedicated to predict the fate of phenanthrene (a PAH model compound) in situ under two remediation options: strategy based on long term natural attenuation without any treatment efforts whereby two future climate changes were tested, and by addition of solvents or surfactants to accelerate the substrate transfer rates. To do so, the PAH model was inserted in the Virtual Soil Platform of INRA including other modules describing the water transfer, heat transport and solute transport as well as the climatic conditions. The performance of the coupled model was tested via a calibration and validation process. Simulation results based on long term natural attenuation showed that i) degradation of PHE was characterized by two degradation phase, ii) PHE removal was governed by substrate transfer limitation from the strongly sorbed compartment into the weakly one and not by the microorganisms, and iii) climatic conditions played a significant role in degradation kinetics but the two prospective climatic scenarios tested lead to very similar PAH concentrations after 50 years of natural attenuation with an overall 54\% decrease. The second option emerged that addition of solvent or surfactants resulted in significant increasing in substrate transfer rate, hence reducing time remediation. However, also increases in toxicity and risk of leaching were noticed. In the future, module associated to plant functions and compost fertilization will be
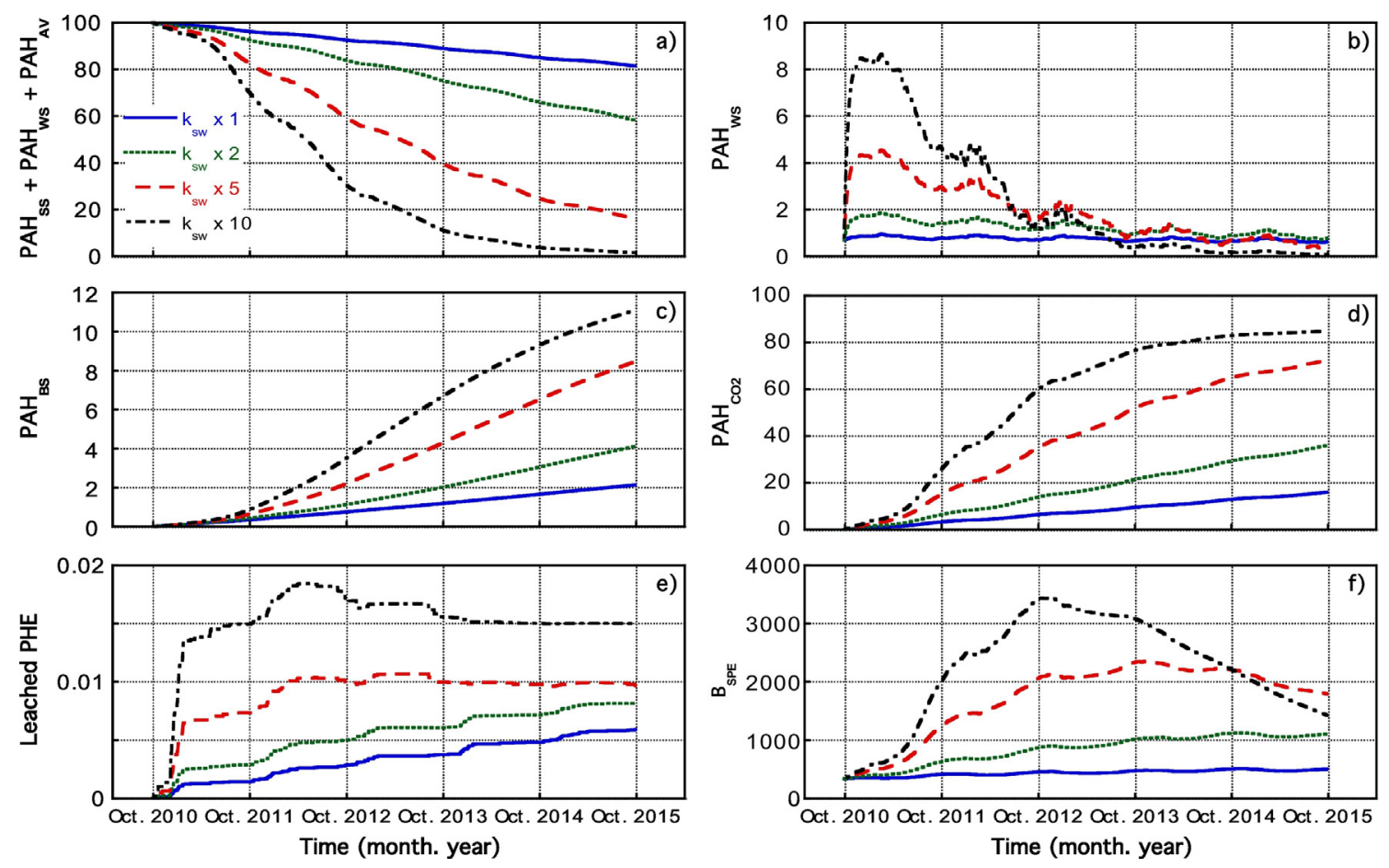

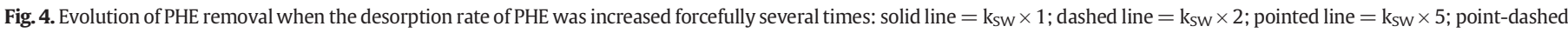

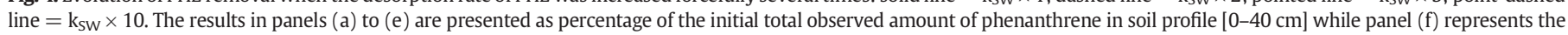
temporal evolution of the specific biomass accumulated in soil profile expressed by unit of $\mathrm{mg} \mathrm{m}^{-2}$. 
integrated in the Virtual Soil platform to simulate the fate of PAH for other type of remediation.

\section{Acknowledgements}

This research was financially supported by the French Environment and Energy Management Agency (ADEME) and the Environment and Agronomy division of the French National Institute for Agricultural Research (INRA) under project number TEZ13-04. We are grateful to the development team of the Virtual Soil Platform: Nicolas Moitrier, Nathalie Moitrier and Cédric Nouguier for their technical help and to Erwan Personne for the fruitful discussions.

\section{Appendix A. Supplementary data}

Supplementary data to this article can be found online at https://doi. org/10.1016/j.scitotenv.2017.11.089.

\section{References}

Adam, I.K.U., Rein, A., Miltner, A., Fulgêncio, A.C.D., Trapp, S., Kästner, M., 2014. Experimental results and integrated modeling of bacterial growth on an insoluble hydrophobic substrate (phenanthrene). Environ. Sci. Technol. 48:8717-8726. https:// doi.org/10.1021/es500004z.

Alletto, L., Coquet, Y., Benoit, P., 2006. Effects of temperature and water content on degradation of isoproturon in three soil profiles. Chemosphere 64:1053-1061. https:// doi.org/10.1016/j.chemosphere.2005.12.004.

Andrén, O., Steen, E., Rajkai, K., 1992. Modelling the effects of moisture on barley straw and root decomposition in the field. Soil Biol. Biochem. 24:727-736. https://doi.org/ 10.1016/0038-0717(92)90246-T.

Aronstein, B., Calvillo, Y., Alexander, M., 1991. Effect of surfactants at low concentrations on the desorption and biodegradation of sorbed aromatic-compounds in soil. Environ. Sci. Technol. 25, 1728-1731.

Barnier, C., Ouvrard, S., Robin, C., Morel, J.L., 2014. Desorption kinetics of PAHs from aged industrial soils for availability assessment. Sci. Total Environ. 470-471:639-645. https://doi.org/10.1016/j.scitotenv.2013.10.032.

Beulke, S., Dubus, I.G., Brown, C.D., Gottesburen, B., 2000. Simulation of pesticide persistence in the field on the basis of laboratory data: a review. Environ. Qual. 29: 1371-1379. https://doi.org/10.2134/jeq2000.00472425002900050001x.

Birdwell, J., Cook, R.L., Thibodeaux, L.J., 2007. Desorption kinetics of hydrophobic organic chemicals from sediment to water: a review of data and models. Environ. Toxicol. Chem. 26, 424-434

Brimo, K., Garnier, P., Sun, S., Bertrand-krajewski, J., Cébron, A., Ouvrard, S., 2016. Using a Bayesian approach to improve and calibrate a dynamic model of polycyclic aromatic hydrocarbons degradation in an industrial contaminated soil. Environ. Pollut. 215: 27-37. https://doi.org/10.1016/j.envpol.2016.04.094.

Cebron, A., Beguiristain, T., Faure, P., Norini, M.-P., Masfaraud, J.-F., Leyval, C., 2009. Influence of vegetation on the in situ bacterial community and polycyclic aromatic hydrocarbon (PAH) degraders in aged PAH-contaminated or thermal-desorption-treated soil. Appl. Environ. Microbiol. 75:6322-6330. https://doi.org/10.1128/AEM.02862-08.

Edwards, N.T., 1983. Polycyclic aromatic hydrocarbons (PAH's) in the terrestria environment-a review. J. Environ. Qual. 12:427-441. https://doi.org/10.2134/ jeq1983.00472425001200040001x.

Fisher, R., 1958. Statistical Methods for Research Workers. 13th ed. Hafner Pub. Co., (New York).

FOCUS, 2006. Guidance Document on Estimating Persistence and Degradation Kinetics From Environmental Fate Studies on Pesticides in EU Registration. Report of the FOCUS Work Group on Degradation Kinetics, EC Document Reference Sanco/1005. pp. $1-436$.

Fragoulis, G., Trevisan, M., Puglisi, E., Capri, E., 2005. A model assessing bioavailability of persistent organic pollutants in soil. Reactive Transport in Soil and Groundwater. Springer-Verlag, Berlin/Heidelberg https://doi.org/10.1007/3-540-26746-8_3.

Garban, B., Blanchoud, H., Motelay-massei, A., Chevreuil, M., Ollivon, D., 2002. Atmospheric bulk deposition of PAHs onto France: trends from urban to remote sites. Atmos. Environ. 36, 5395-5403.

Garnier, P., Néel, C., Mary, B., Lafolie, F., 2001. Evaluation of a nitrogen transport and transformation model in a bare soil. Eur. J. Soil Sci. 52, 253-268.

Geng, C., Haudin, C.-S., Zhang, Y., Lashermes, G., Houot, S., Garnier, P., 2015. Modeling the release of organic contaminants during compost decomposition in soil. Chemosphere 119:423-431. https://doi.org/10.1016/j.chemosphere.2014.06.090.

Gustafson, K.E., Dickhut, R.M., 1994. Molecular diffusivity of polycyclic aromatic hydrocarbons in aqueous solution. J. Chem. Eng. Data 39:281-285. https://doi.org/10.1021/ je00014a019.

Houghton, J.T., Ding, Y., Griggs, D.J., Noguer, M., van der Linden, P.J., Dai, X., Maskell, K., Johnson, C.A., 2001. Climate change 2001: the scientific basis. Contribution of Working Group I to the Third Assessment Report of the Intergovernmental Panel on Climate Change (IPCC).

Iarc, 2010. IARC monographs on the evaluation of carcinogenic risks to humans: some non-heterocyclic polycyclic aromatic hydrocarbons and some related exposures. IARC Monogr. Eval. Carcinog. Risks Hum. 92, 1-868.
Johnson, M.D., Keinath, T.M., Weber, W.J., 2001. A distributed reactivity model for sorption by soils and sediments. 14. Characterization and modeling of phenanthrene desorption rates. Environ. Sci. Technol. 35:1688-1695. https://doi.org/10.1021/ es001391k.

Kästner, M., Nowak, K.M., Miltner, A., Trapp, S., Schäffer, A., 2014. Classification and modelling of nonextractable residue (NER) formation of xenobiotics in soil - a synthesis. Crit. Rev. Environ. Sci. Technol. 44, 2107-2171.

Keuth, S., Rehm, H.-J., 1991. Biodegradation of phenanthrene by Arthrobacter polychromogenes isolated from a contaminated soil. Appl. Microbiol. Biotechnol. 34 (6), 804-808.

Lafolie, F., 1991. Modelling water flow, nitrogen transport and root uptake including physical non-equilibrium and optimization of the root water potential. Nutr. Cycl. Agroecosyst. 27:215-231. https://doi.org/10.1007/BF01051129.

Lafolie, F., Cousin, I., Marron, P.-A., Mollier, A., Pot, V., Moitrier, N., Moitrier, N., Nouguier, C., 2014. The "VSOIL" modeling platform. Rev. For. Fr. LXVI, hors série 2014 (ISSN 0035). https://doi.org/10.4267/2042/56287.

Laha, S., Tansel, B., Ussawarujikulchai, A., 2009. Surfactant-soil interactions during surfactant-amended remediation of contaminated soils by hydrophobic organic compounds: a review. J. Environ. Manag. 90, 95-100.

Li, J.-L., Chen, B.-H., 2009. Surfactant-mediated biodegradation of polycyclic aromatic hydrocarbons. Materials (Basel) 2:76-94. https://doi.org/10.3390/ma2010076.

Mackay, D., Shiu, W.Y., Ma, K., Lee, S.C., 2006. Handbook of Physical-Chemical Properties and Environmental Fate for Organic Chemicals. 2nd ed. CRC Press, Boca Raton (FL).

Madesen, T., Kristensen, P., 1997. Effects of bacterial inoculation and nonionic surfactants on degradation of polycyclic aromatic hydrocarbons in soil. Environ. Toxicol. Chem. $16,631-637$.

Mosche, M., Meyer, U., 2002. Toxicity of linear alkylbenzene sulfonate in anaerobic digestion: influence of exposure time. Water Res. 36, 3253-3260.

Mualem, Y., 1976. A new model to predicting the hydraulic conductivity of unsaturated porous media. Water Resour. Res. 12, 513-522.

Nakicenovic, N., Swart, R., 2000. Emissions Scenarios. IPCC, Cambridge University Press, UK, p. 570 .

Nash, J.E., Sutcliffe, J.V., 1970. River flow forecasting through conceptual models part I - a discussion of principles. J. Hydrol. 10:282-290. https://doi.org/10.1016/00221694(70)90255-6.

Nguyen, T.H., Goss, K.-U., Ball, W.P., 2005. Polyparameter linear free energy relationships for estimating the equilibrium partition of organic compounds between water and the natural organic matter in soils and sediments. Environ. Sci. Technol. 39: 913-924. https://doi.org/10.1021/es048839s.

Ouvrard, S., Barnier, C., Bauda, P., Beguiristain, T., Biache, C., Bonnard, M., Caupert, C., Cébron, A., Cortet, J., Cotelle, S., Dazy, M., Faure, P., Masfaraud, J.F., Nahmani, J., Palais, F., Poupin, P., Raoult, N., Vasseur, P., Morel, J.L., Leyval, C., 2011. In situ assessment of phytotechnologies for multicontaminated soil management. Int. J. Phytoremed. 13:245-263. https://doi.org/10.1080/ 15226514.2011.568546.

Peters, C.A., Knightes, C.D., Brown, D.G., 1999. Long-term composition dynamics of PAHcontaining NAPLs and implications for risk assessment. Environ. Sci. Technol. 4499-4507.

Power, M., 1993. The predictive validation of ecological and environmental models. Ecol. Model. 68, 33-50.

Recous, S., 1995. Soil inorganic N availability: effect on maize residue decomposition. Soil Biol. Biochem. 27, 1529-1538.

Rein, A., Adam, I.K.U., Miltner, A., Brumme, K., Kästner, M., Trapp, S., 2016. Impact of bacterial activity on turnover of insoluble hydrophobic substrates (phenanthrene and pyrene) - model simulations for prediction of bioremediation success. J. Hazard. Mater. 306:105-114. https://doi.org/10.1016/j.jhazmat.2015.12.005.

Richards, L.A., 1931. Capillary conduction of liquids through porous mediums. J. Appl. Phys. 1:318-333 (Physics). https://doi.org/10.1063/1.1745010.

Schaap, M.G., Leij, F.J., van Genuchten, M.T., 2001. ROSETTA: a computer program for estimating soil hydraulic parameters with hierarchical pedotransfer functions. J. Hydrol. $251,163-176$.

Schulze-Makuch, D., 2005. Longitudinal dispersivity data and implications for scaling behavior. Ground Water 43 (3):443-456. https://doi.org/10.1111/j.17456584.2005.0051.x.

Séré, G., Ouvrard, S., Magnenet, V., Pey, B., Morel, J.L., Schwartz, C., 2012. Predictability of the evolution on of the soil structure using water flow modeling for a constructed technosol. Vadose Zone J. 11:111-123. https://doi.org/10.2136/ vzj2011.0069.

Soutter, M., Musy, A., 1999. Global sensitivity analyses of three pesticide leaching models using a Monte-Carlo approach. J. Environ. Qual. 28, 1290-1297.

Takaki, K., Wade, A.J., Collins, C.D., 2014. Assessment of plant uptake models used in exposure assessment tools for soils contaminated with organic pollutants. Environ. Sci. Technol. 48, 12073-12082.

Tao, X.-Q., Lu, G.-N., Dang, Z., Yi, X.-Y., Yang, C., 2007. Isolation of phenanthrene-degrading bacteria and characterization of phenanthrene metabolites. World J. Microbiol. Biotechnol. 23:647-654. https://doi.org/10.1007/s11274-006-9276-4.

Thiele-Bruhn, S., Brümmer, G.W., 2005. Kinetics of polycyclic aromatic hydrocarbon (PAH) degradation in long-term polluted soils during bioremediation. Plant Soil 275:31-42. https://doi.org/10.1007/s11104-004-0265-9.

Tiktak, A., van der Linden, A.M.A., Swartjes, F., 1994. PESTRAS: a one dimensional model for assessing leaching and accumulation of pesticides in soil. RIVM Report (715501003).

Tsibart, A.S., Gennadiev, A.N., 2013. Polycyclic aromatic hydrocarbons in soils: sources, behavior, and indication significance (a review). Eurasian Soil Sci. 46:728-741. https:// doi.org/10.1134/S1064229313070090.

Van Genuchten, M.T., 1980. A closed-form equation for predicting the hydraulic conductivity of unsaturated soils. Soil Sci. Soc. Am. J. 44, 892-898. 
Volkering, F., Breure, A.M., Sterkenburg, A., 1992. Microbial degradation of polycyclic aromatic hydrocarbons: effect of substrate availability on bacterial growth kinetics. Environ. Biotechnol. 36, 548-552.

Weissenfels, W.D., Beyer, M., Klein, J., 1990. Degradation of phenanthrene, fluorene and fluoranthene by pure bacterial cultures. Appl. Microbiol. Biotechnol. 32:479-484. https://doi.org/10.1007/BF00903787.
Wick, L.Y., Colangelo, T., Harms, H., 2001. Kinetics of mass transfer-limited bacterial growth on solid PAHs. Environ. Sci. Technol. 35, 354-361.

Wilcke, W., 2000. SYNOPSIS polycyclic aromatic hydrocarbons (PAHs) in soil - a review. J. Plant Nutr. Soil Sci. 163:229-248. https://doi.org/10.1002/1522-2624(200006)163: 3<229::AID-JPLN229>3.0.CO;2-6. 